\title{
PERANCANGAN WEB E-COMMERCE UNTUK PENJUALAN SEPATU DENGAN PENDEKATAN MODEL CLASSIC LIFE CYCLE
}

\author{
${ }^{1}$ Ika Yuniva, ${ }^{2}$ Dany Hestiyanto \\ ${ }^{1,2}$ Manajemen Informatika, AMIK BSI Tangerang \\ E-mail: 1ika.iya@bsi.ac.id, ${ }^{2}$ dany.hestiyanto41@gmail.com
}

\begin{abstract}
Abstrak
Sebuah Website tidak hanya digunakan sebagai media informasi, namun juga digunakan sebagai media promosi baik di bidang usaha dagang, jasa dan lain sebagainya. Salah satunya sebuah Home Industry Sepatu membutuhkan media promosi melalui website untuk memperluas pemasaran sehingga menunjang pendapatan penjualan dan memberikan kemudahan bagi siapa saja yang membutuhkan Sepatu buatan Home Industry. Rizky Shoes merupakan sebuah Home Industry yang bergerak dalam bidang pembuatan dan penjualan Sepatu Handmade.Saat ini proses pemesanan dan penjualan masih konvensional, pelanggan dapat datang langsung ke Home Industry Rizky Shoes dan pencatatan transaksi masih manual menggunakan kertas. Tujuan penelitian ini untuk menghasilkan sebuah website e-commerce sebagai media promosi dan pemasaran dan membantu Home Industry Rizky Shoes dalam meningkatkan penjualan. Bentuk penelitian ini menggunakan studi kasus dengan metode observasi dan studi pustaka dalam mengumpulkan data. Kebutuhan sistem pada web ecommerce ini Admin dapat melakukan proses input barang, menampilkan data maupun proses penghapusan data, mengubah status pembelian. Sedangkan user dapat melakukan pemesanan, melihat produk, mendaftar sebagai member, dan melakukan konfirmasi pembayaran. Untuk metode pengembangan perangkat lunak menggunakan pendekatan classic life cycle. Model data digambarkan oleh ERD (Entity Relationship Diagram) dan LRS ( Logical Record Structure) Sedangkan basis data menggunakan MySQL dan bahasa pemograman menggunakan PHP.
\end{abstract}

Kata Kunci-E-Commerce, Sepatu, Home Industry

\begin{abstract}
A Website is not only used as a medium of information, but also used as a media campaign both in the field of business, service and so forth. One of them a Home Industry Shoes require promotion media through the website to expand the marketing so as to support sales revenue and provide convenience for anyone who needs Shoes made Home Industry. Rizky Shoes is a Home Industry engaged in the manufacture and sale of Handmade Shoes. Currently the ordering and sales process is still conventional, customers can come directly to the Home Industry Rizky Shoes and recording transactions are still manual using paper. The purpose of this study is to produce an e-commerce website as a media campaign and marketing and help Home Industry Rizky Shoes in increasing sales. This research uses case study with observation method and literature study in collecting data. System requirements on this e-commerce web Admin can make the process of goods input, display data or data deletion process, change the status of purchases. While users can make reservations, view products, register as a member, and make payment confirmation. For software development method using classic life cycle approach. Data model described by ERD (Entity Relationship Diagram) and LRS (Logical Record Structure) While the database using MySQL and programming languages using PHP
\end{abstract}

Keywords-E-Commerce, Shoes, Home Industry 


\section{PENDAhUluan}

Home Industry Rizky Shoes merupakan sebuah usaha bisnis dalam bidang penjualan sepatu handmade di daerah Tangerang. Beberapa home industry dalam memasarkan produk mereka sangatlah bersaing. Sehingga diperlukan sebuah strategi dalam memasarkan dan mempromosikan produk yaitu dengan memanfaatkan website. Sudah sangat berkembang pesat di beberapa negara terutama Indonesia dalam penggunaan website. Banyak perusahaan maupun Usaha Kecil Menengah ( UKM ) atau juga Home Industry memanfaatkan website sebagai langkah strategi untuk menawarkan produk mereka kepada konsumen tanpa di batasi ruang dan waktu. Selama ini home industry Rizky Shoes sistem penjualannya masih konvensional, dalam hal ini pelanggan datang langsung ke Rizky Shoes untuk melakukan pembelian sepatu. Selain itu dengan sistem konvensional, Home Industry Rizky Shoes mengalami kesulitan untuk memasarkan produk sepatu ke beberapa daerah dan pencatatan transaksi penjualannya pun masih manual menggunakan kertas. Untuk membantu Home Industry Rizky Shoes dalam memasarkan produk, mempromosikan dan meningkatkan pendatapan penjualan, maka penulis merancang sebuah Web E-Commerce. Adapun Permasalahan yang dihadapi antara lain:

1. Dalam proses penjualan dan pemesanan sepatu masih konvensional, pelanggan datang langsung ke Home Industry Rizky Shoes.

2. Media promosi dan pemasaran masih konvensional, menggunakan spanduk.

3. Pencatatan transaksi masih manual menggunakan kertas.

Tujuan Penelitian ini dimaksudkan untuk:

1. Merancang sebuah web e-commerce pada Home Indsustry Rizky Shoes untuk memudahkan dalam proses pemesanan sepatu.

2. Memudahkan Home Industry Rizky Shoes dalam memasarkan dan mempromosikan sepatu menggunakan website.

3. Memudahkan Home Industry Rizky Shoes dalam mengolah data transaksi penjualan.

\section{A. Kajian Literatur}

\section{Website}

Website dapat diartikan sebagai kumpulan halaman yang menampilkan informasi data teks, data gambar diam atau gerak, data animasi, suara, video dan atau gabungan dari semuanya, baik yang bersifat statis maupun dinamis yang membentuk satu rangkaian bangunan yang saling terkait dimana masing-masing dihubungkan dengan jaringan-jaringan halaman (hyperlink).[1]

\section{E-Commerce}

E-commerce adalah pembelian, penjualan, dan pemasaran barang serta jasa melalui sistem elektronik seperti televisi, radio, jaringan komputer atau internet. Juga dapat didefinisikan sebagai suatu cara berbelanja atau berdagang dengan online atau direct selling yang memanfaatkan fasilitas internet dimana terdapat website yang menyediakan layanan get and delivery"[2]

\section{PHP ( Hypertext Preprocessor)}

Sebuah bahasa pemograman web berbasis server (server-side) yang mampu mem-parshing kode php dari kode web dengan ektensi php, sehingga menghasilkan tampilan website yang dinamis di sisi client ( browser)[3]

\section{MySQL}

MySQL merupakan database yang dikembangkan dari bahasa SQL ( Structure Query Languange). SQL merupakan bahasa terstruktur yang digunakan untuk interaksi antara script program dengan database server dalam hal pengolahan data.[4].

5. Pengembangan Perangkat Lunak

SDLC atau lebih dikenal System Development Life Cycle adalah proses mengembangkan atau mengubah suatu system perangkat lunak dengan model-model dan metodologi yang digunakan orang untuk mengembangkan sistem-sistem perangkat lunak sebelumnya ( berdasarkan best practice atau cara-cara yang sudah teruji baik)[5]. Model pengembangan Sistem Informasi : 
a.Model sekuensial linier (clasic life cycle/waterfall model), terdiri dari tahapan perencanaan sistem (rekayasa sistem), analisa kebutuhan, desain, penulisan program, pengujian dan perawatan sistem.

b.Model prototype (prototyping model), dimulai dengan pengumpulan kebutuhan dan perbaikan, desain cepat, pembentukan prototipe, evaluasi pelanggan terhadap prototipe, perbaikan prototipe dan produk akhir.

c.Rapid Application Development (RAD) model, dengan kegiatan dimulai pemodelan bisnis, pemodelan data, pemodelan proses, pembangkitan aplikasi dan pengujian

d.Model evolusioner yang dapat berupa model incremental atau model spiral. Model incremental merupakan gabungan model sekuensial linier dengan prototyping (misalnya perangkat lunak pengolah kata dengan berbagai versi). Sedangkan model spiral menekan adanya analisa resiko. Jika analisa resiko menunjukkan ada ketidakpastian terhadap kebutuhan, maka pengembangan sistem dapat dihentikan.

6. ERD

Entity Relationship Diagram ( ERD ) adalah diagram yang berisi komponen- komponen himpunan entitas dan himpunan relasi yang masing-masing dilengkapi dengan atribut-atribut yang mempresentasikan seluruh fakta dari dunia nyata yang kita tinjau"[6]

7. LRS

LRS (Logical Record Structured) adalah sebuah model sistem yang digambarkan dengan sebuah diagram E-R akan mengikuti pola/aturan pemodelan tertentu dalam kaitannya dengan konversi ke LRS.[7]

8. Pengujian Web

Black-Box Testing (pengujian Kotak Hitam) . Black-box yaitu menguji perangkat lunak dari segi spesifikasi fungsional tanpa menguji desain dan kode program. Pengujian dimaksudkan untuk mengetahui apakah fungsi-fungsi, masukan, dan keluaran dari perangkat lunak sesuai dengan spesifikasi yang dibutuhkan.[8]

B. Penelitian terkait

Anggi Oktaviani [9] dalam jurnalnya yang berjudul "E-commerce merchandise $k$-pop pada Toko Haruna 88 Jakarta menggunakan UML ( Unified Modeling Languange ). Penelitian ini menggunakan UML untuk merancang sistem, sedangkan database MySql dan bahasa pemograman menggunakan PHP dalam membuat web. Dalam penelitian ini menjelaskan bahwa untuk mendapatkan berbagai pernak-pernik K-Pop diperlukan sebuah web e-commerce untuk mempermudah pelanggan yang ingin membeli tanpa harus datang langsung ke Toko. Hasil dari penelitian diharapkan dapat lebih mudah untuk mempublikasikan penjualan lebih luas serta dapat sangat membantu dalam kegiatan bertransaksi secara efektif dan efisien.

Jony Pranata Sentosa dan Nunung Hidayatun[10] dalam jurnalnya yang berjudul "Pendekatan Classic Life Cycle Dalam Perancangan Web E-Commerce Untuk Penjualan Pakaian Anime". Penjualan pakaian anime merupakan bisnis usaha dengan menjual pakaian seperti T-Shirt, Polo tshirt, hoodie dan sweater dengan design animasi jepang. Dalam penelitian ini menggunakan metode pengembangan perangkat lunak dengan pendekatan Classic Life Cycle, dengan teknik pengumpulan data yaitu pengamatan dan studi pustaka. Hasil yang dicapai dalam penelitian ini diharapkan dengan dibuatnya sebuah website e-commerce pakaian anime dapat menguntungkan pihak distro dan pecinta anime dalam penjualannya.

Tony Wijaya dan Dony Pratama[11] dalam jurnalnya yang berjudul "Rancang Bangun Website E-Commerce Pada Barcelona Sport", menjelaskan bahwa penelitian ini menggunakan pendekatan Icremental Development dan Pemodelannya menggunakan diagram Use Case, Activity, Sequence dan Class Diagram dalam merancang website e-commerce pada Barcelona Sport. Hasil dari penelitian ini untuk menghasilkan sebuah aplikasi E-Commerce yang dapat dipergunakan untuk memenuhi kebutuhan permintaan pasar dan mencari peluang pasar yang baru. 


\section{METODE PENELITIAN}

A. Teknik Pengumpulan Data

1. Observasi

Melalukan pengamatan pada Home Industry Sepatu Handmade Rizky Shoes di Tangerang dan pada beberapa situs yang bersangkutan.

2. Studi pustaka

Melakukan studi pustaka dengan mengambil beberapa referensi baik dari artikel jurnal dan buku.

B. Metode Pengembangan Sistem

Metode yang digunakan pada pengembangan perangkat lunak ini menggunakan pendekatan model classic life cycle atau waterfall. Pada model ini terdapat beberapa tahapan yaitu :

1. Analisa Kebutuhan Sistem

Dalam merancang website e-commerce penjualan sepatu ini, penulis menggunakan beberapa sistem pendukung diantaranya: Adobe Dreamweaver CS6, Mozilla Firefox, dan XAMPP .

2. Desain

Menggunakan MYSQL dalam merancang database dan tabel. Desain antarmuka disesuaikan dengan tampilan website yang menyesuaikan dengan layar pengunjung.

3. Code Generation

Penulis menggunakan bahasa pemograman PHP dan HTML dalam membuat script coding program.

4. Testing

Penulis menggunakan Black Box Testing untuk mengetahui apakah sistem informasi penjualan yang telah dibuat sudah sesuai apa belum, agar tidak terjadi kesalahan pada saat dijalankan.

5. Support

Untuk menjalankan sistem informasi penjualan yang telah dibuat, diperlukan suatu hardware sebagai pendukung sistemnya, yaitu CPU, hardisk, monitor, mouse, keyboard. Sedangkan software pendukungnya yaitu sistem operasi Microsoft Windows, Database Server MySQL, Database tool PhpMyadmin dan Web server Xampp.

\section{HASIL DAN PEMBAHASAN}

Berdasarkan hasil analisa tentang kebutuhan yang diperlukan, maka rancangan basis data dan tampilan antar muka dari rancangan website $e$-commerce penjualan sepatu yaitu sebagai berikut:

A. Rancangan Basis Data

1. ERD (Entity Relationship Diagram ) pada Perancangan Web E-Commerce Untuk Penjualan Sepatu 


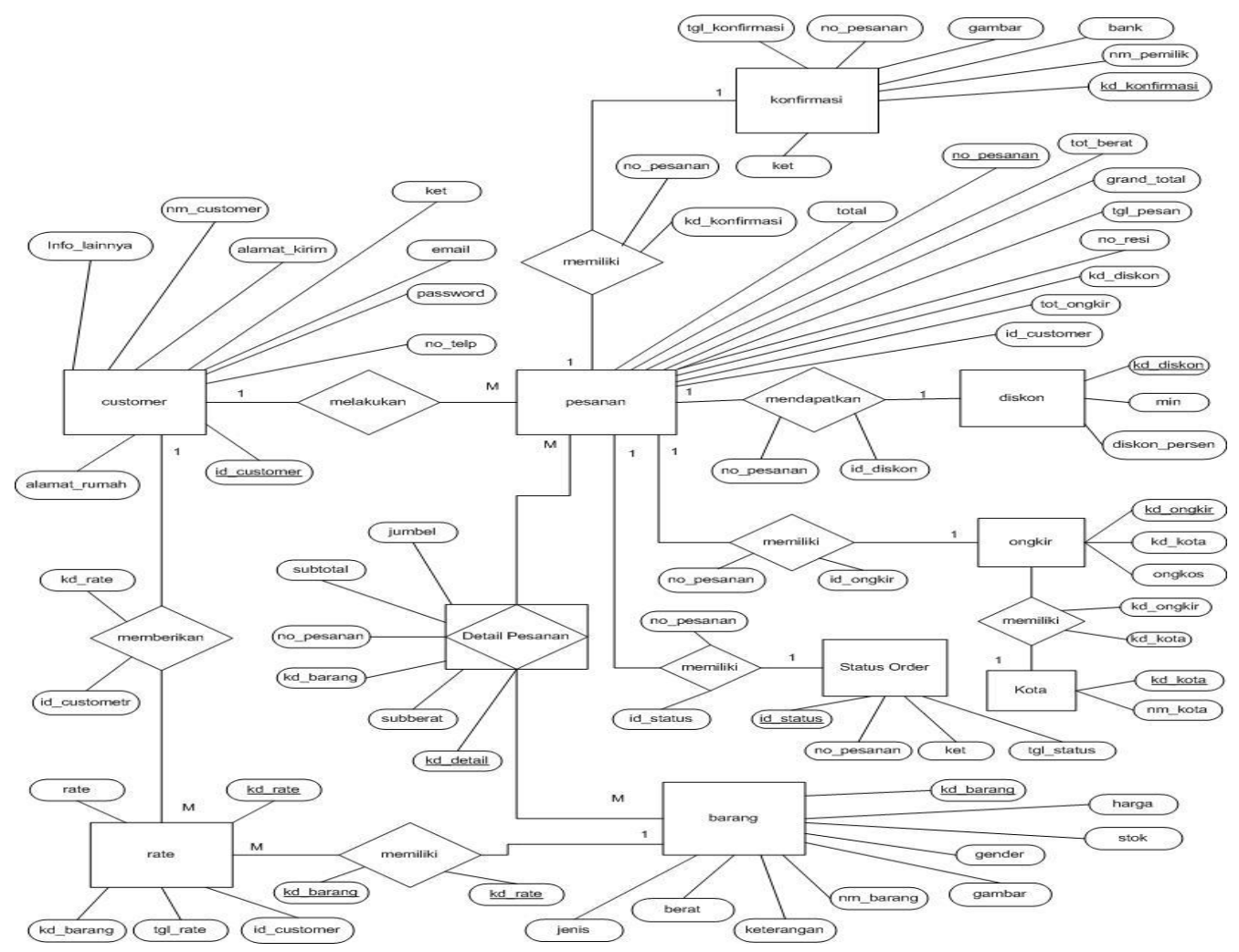

Gambar 1. Entity Relationship Diagram ( ERD )

2. LRS (Logical Record Structured) Pada Perancangan Web E-Commerce Untuk Penjualan Sepatu

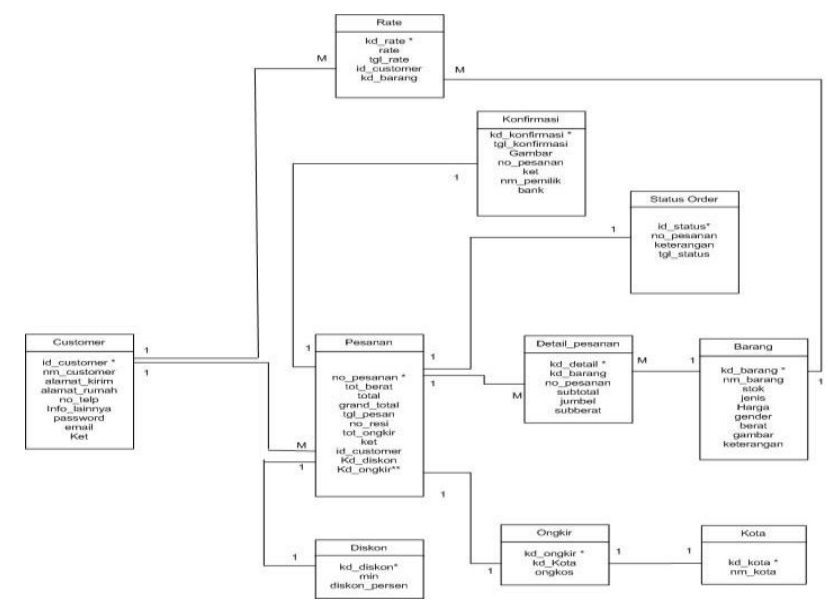

Gambar 2. LRS (LRS (Logical Record Structured)

B. Rancangan Struktur Navigasi

Rancangan Struktur Navigasi Pada Perancangan Web E-Commerce Untuk Penjualan Sepatu ( Studi Kasus : Home Industry Rizky Shoes ) 
1. Rancangan Struktur Navigasi Halaman User

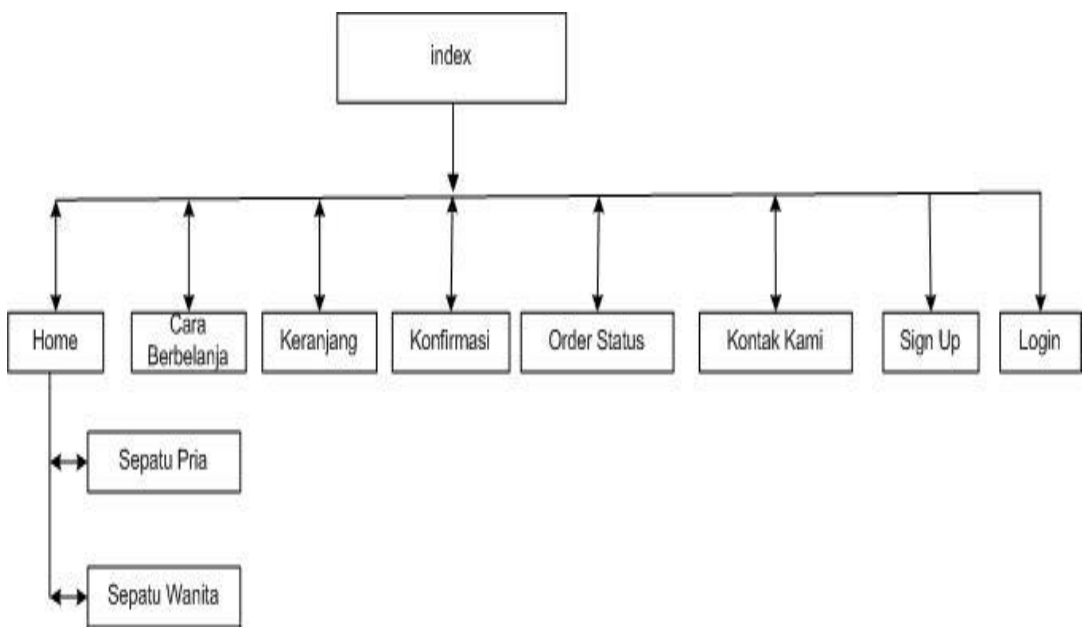

Gambar 3. Struktur Navigasi Halaman User

2. Rancangan Struktur Navigasi Halaman Admin

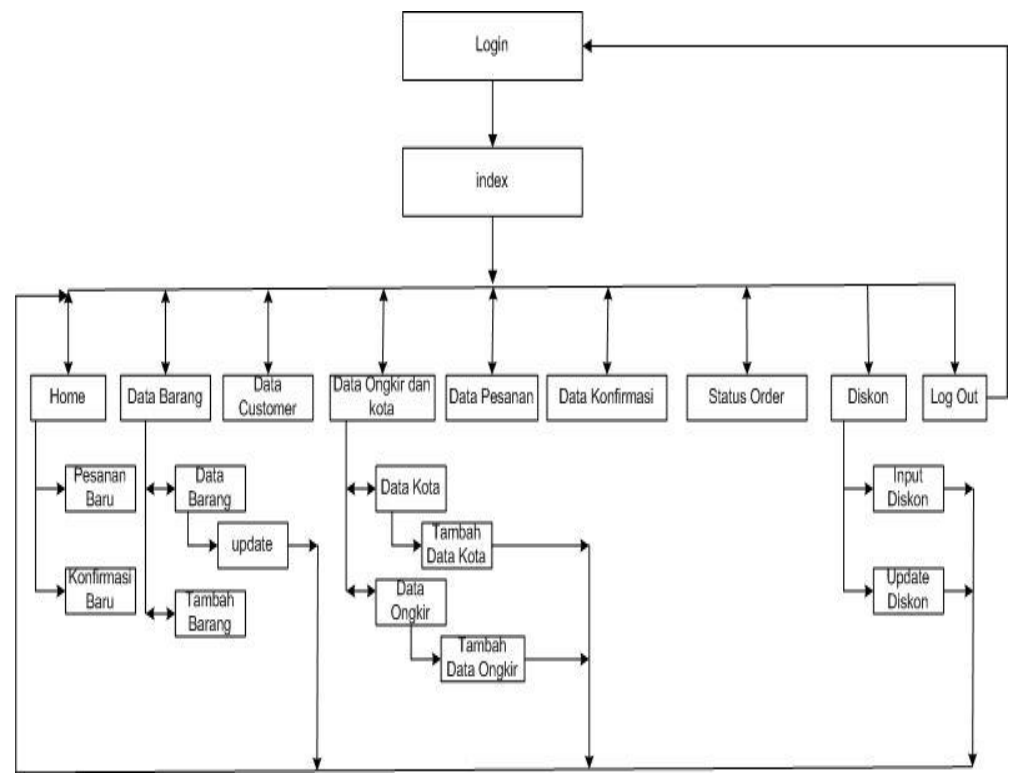

Gambar 4. Struktur Navigasi Halaman Admin

B. Desain Interface

1. Tampilan Home User

Di halaman user terdapat menu home yang kontenya berisi tentang promosi web serta daftar barang yang dijual. 


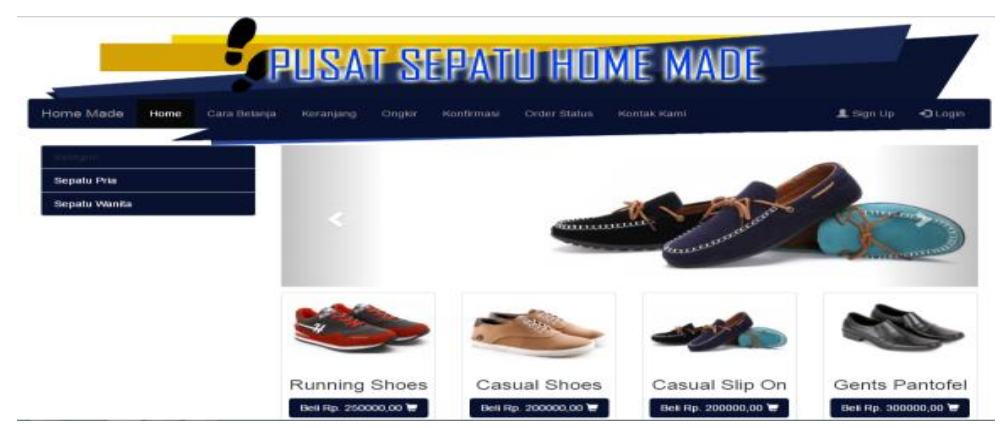

Gambar 5. Halaman User

2. Tampilan Ruang Admin

Admin harus melakukan login terlebih dahulu untuk dapat menggunakan modul-modul yang tersedia. Jika login berhasil, maka menu-menu yang sesuai dengan kategori admin tersebut akan ditampilkan

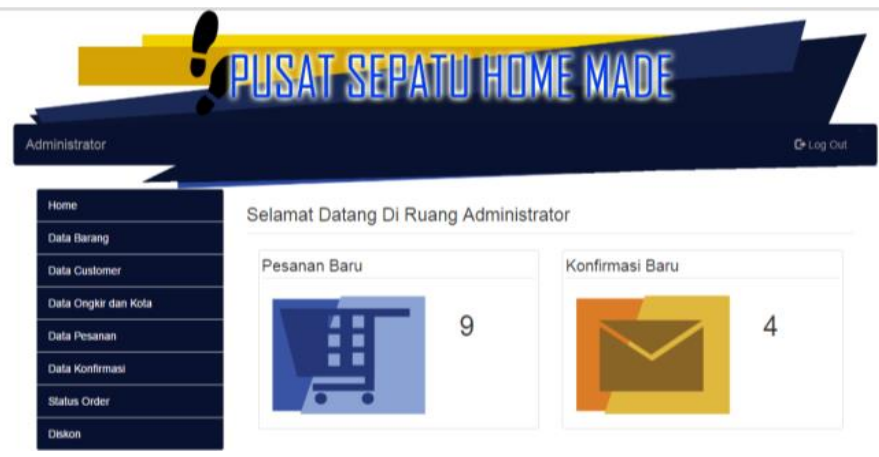

Gambar 6. Ruang Admin

3. Tampilan Cetak Transaksi User

Di halaman user terdapat halaman cetak transaksi yang kontennya berisi struk pesanan barang serta alamat pengiriman barang.

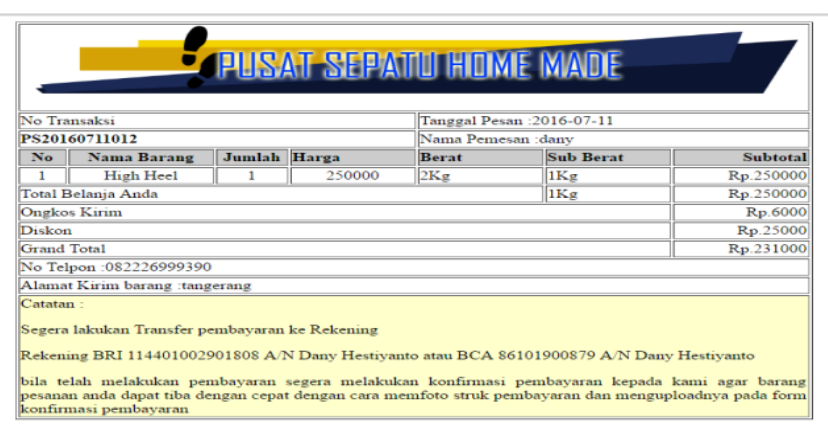

Gambar 7. Cetak transaksi user

4. Tampilan Data Pembayaran User

Di halaman user terdapat halaman pembayaran yang kontennya berisi tentang jumlah harga barang serta alamat pengiriman barang. 


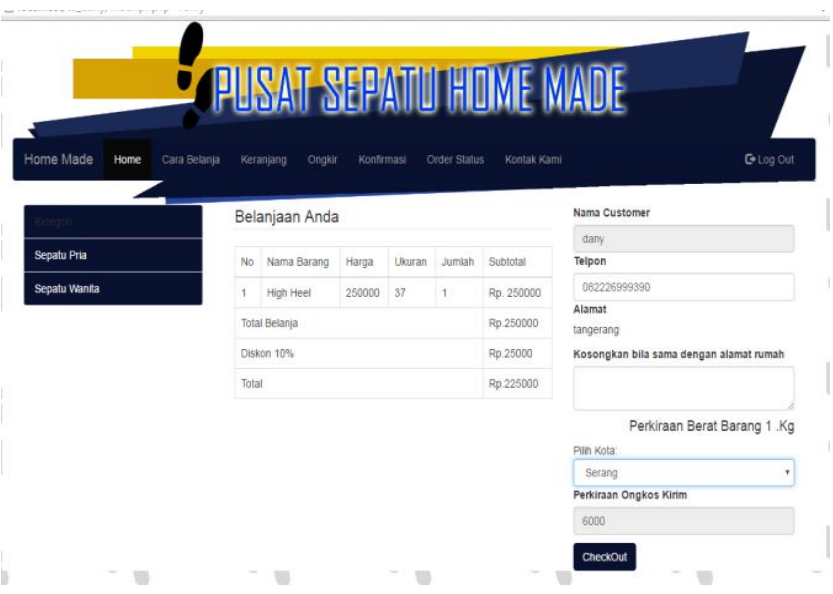

Gambar 8. Data Pembayaran User

D. BLACK BOX TESTING

Pengujian terhadap program web yang dibuat menggunakan black box testing yang fokus terhadap proses masukan dan keluaran program. Dan hasil black box testing sebagai berikut:

Tabel 1.Black Box Testing Halaman Login Admin

\begin{tabular}{|c|c|c|c|c|c|}
\hline No & Sekenario pengujian & Test case & $\begin{array}{l}\text { Hasil yang } \\
\text { diharapkan }\end{array}$ & $\begin{array}{c}\text { Hasil } \\
\text { pengujian }\end{array}$ & Kesimpulan \\
\hline 1 & $\begin{array}{l}\text { Mengosongkan } \\
\text { semua isian lalu } \\
\text { menekan tombol } \\
\text { "login" }\end{array}$ & $\begin{array}{l}\text { User Id: (kosong) } \\
\text { Password: } \\
\text { (kosong) }\end{array}$ & $\begin{array}{l}\text { Sistem akan } \\
\text { menampilkan } \\
\text { "please fill out this } \\
\text { field" pada textbox } \\
\text { user id }\end{array}$ & $\begin{array}{l}\text { Sesuai } \\
\text { harapan }\end{array}$ & Valid \\
\hline 2. & $\begin{array}{l}\text { Hanya mengisi salah } \\
\text { satu kolom isian lalu } \\
\text { menekan tombol } \\
\text { "login" }\end{array}$ & $\begin{array}{l}\text { User Id: } 1234 \\
\text { Password: } \\
\text { (kosong) }\end{array}$ & $\begin{array}{l}\text { Sistem akan } \\
\text { menampilkan } \\
\text { "please fill out this } \\
\text { field" pada textbox } \\
\text { password }\end{array}$ & $\begin{array}{c}\text { Sesuai } \\
\text { harapan }\end{array}$ & Valid \\
\hline 3 & $\begin{array}{l}\text { Mengisi User Id } \\
\text { yang salah dan } \\
\text { mengisi password } \\
\text { dengan benar }\end{array}$ & $\begin{array}{l}\text { User Id: } 1235 \\
\text { Password: admin }\end{array}$ & $\begin{array}{l}\text { Sistem akan } \\
\text { menolak dengan } \\
\text { menampilkan "id } \\
\text { admin atau } \\
\text { password salah" }\end{array}$ & $\begin{array}{l}\text { Sesuai } \\
\text { Harapan }\end{array}$ & Valid \\
\hline 4 & $\begin{array}{l}\text { Memasukan semua } \\
\text { data denga benar } \\
\text { lalu menekan } \\
\text { tombol "login" }\end{array}$ & $\begin{array}{l}\text { User Id: admin } \\
\text { Password: admin }\end{array}$ & $\begin{array}{l}\text { Sistem menerima } \\
\text { dengan } \\
\text { menampilkan } \\
\text { "berhasil } \\
\text { login,selamat } \\
\text { datang" }\end{array}$ & $\begin{array}{c}\text { Sesuai } \\
\text { harapan }\end{array}$ & Valid \\
\hline
\end{tabular}

Tabel 2. .Black Box Testing Halaman Keranjang Belanja

\begin{tabular}{|l|l|l|l|l|l|}
\hline No & $\begin{array}{c}\text { Sekenario } \\
\text { pengujian }\end{array}$ & Test case & $\begin{array}{c}\text { Hasil yang } \\
\text { diharapkan }\end{array}$ & $\begin{array}{c}\text { Hasil } \\
\text { pengujian }\end{array}$ & Kesimpulan \\
\hline
\end{tabular}




\begin{tabular}{|c|c|c|c|c|c|}
\hline 1 & $\begin{array}{l}\text { Mengosongkan } \\
\text { semua isian lalu } \\
\text { menekan tombol } \\
\text { "upload" }\end{array}$ & $\begin{array}{l}\text { No pesanan: (kosong) } \\
\text { Nama pemilik rekening: } \\
\text { (kosong) } \\
\text { bank: (kosong) } \\
\text { gambar: (kosong) }\end{array}$ & $\begin{array}{l}\text { Sistem akan } \\
\text { menampilkan } \\
\text { "please fill out } \\
\text { this field" } \\
\text { Pada textbox } \\
\text { no pesanan }\end{array}$ & $\begin{array}{c}\text { Sesuai } \\
\text { harapan }\end{array}$ & Valid \\
\hline 2. & $\begin{array}{lr}\text { Hanya } & \text { mengisi } \\
\text { salah satu } & \text { kolom } \\
\text { isian } & \text { lalu } \\
\text { menekan } & \text { tombol } \\
\text { "submit" } & \end{array}$ & $\begin{array}{l}\text { No pesanan: } \\
\text { PS20160612001 } \\
\text { Nama pemilik rekening: } \\
\text { (kosong) } \\
\text { Bank: (kosong) } \\
\text { Gambar: (kosong) }\end{array}$ & $\begin{array}{l}\text { Sistem akan } \\
\text { menampilkan } \\
\text { "please fill out } \\
\text { this field" } \\
\text { Pada textbox } \\
\text { gambar }\end{array}$ & $\begin{array}{c}\text { Sesuai } \\
\text { harapan }\end{array}$ & Valid \\
\hline 3. & $\begin{array}{l}\text { Memasukkan } \\
\text { semua data } \\
\text { dengan benar lalu } \\
\text { menekan } \\
\text { "submit" }\end{array}$ & $\begin{array}{l}\text { No pesanan: } \\
\text { PS20160612001 } \\
\text { Nama pemilik rekening: } \\
\text { Dany Hestiyanto } \\
\text { Bank: Mandiri } \\
\text { Gambar: gambar struk }\end{array}$ & $\begin{array}{l}\text { Sistem akan } \\
\text { menampilkan } \\
\text { "data berhasil } \\
\text { masuk" }\end{array}$ & $\begin{array}{c}\text { Sesuai } \\
\text { Harapan }\end{array}$ & Valid \\
\hline
\end{tabular}

\section{KESIMPULAN}

Penulis mencoba menarik kesimpulan dari pembahasan sebelumnya yaitu :

1. Dengan adanya Rancangan Web E-Commerce Penjualan Sepatu ini diharapkan dapat dan memudahkan pelanggan dalam memesan sepatu dan meningkatkan pendapatan penjualan.

2. Mempermudah pengelola sebuah Home Industry untuk memasarkan produk sepatu mereka.

3. Mempermudah pengelolaan data transaksi penjualan dan meminimalisir kesalahan.

\section{SARAN}

Penulis memberikan beberapa saran yang dapat menjadi tolak ukur untuk perancangan web $e$ commerce yang lebih baik serta web berjalan dengan optimal. Berikut saran-saran yang dapat penulis berikan :

1. Diperlukan adanya backup data yang disimpan untuk meminimalisir kesalahan.

2. Perlu adanya penambahan menu atau fitur yang menarik lebih banyak pengunjung karena rancangan web e-commerce yang penulis buat belumlah sempurna dan maksimal.

3. Diharapkan adanya pemeliharaan software dan hardware untuk keberlangsungan web e-commerce ini.

\section{DAFTAR PUSTAKA}

[1] Adhi, Prasetio, 2010, Cara Mudah Membuat Desain Web Untuk Pemula. Media Kita, Jakarta

[2] Wong,Jony, 2010, Internet Marketing For Beginners, Elex MediaKomputindo, Jakarta.

[3] Edy, Winarno, Ali Zaki dan Smitdev Community, 2011, Resep Top PHP Untuk Programmer Pemula, Elex Media Komputindo, Jakarta.

[4] Sugiri dan Haris Saputro, 2008, Pengelolaan Database MySQL Dengan PhpMyadmin, Graha Ilmu, Yogyakarta.

[5] S, Rosa A dan M. Shalahuddin, 2014, Rekayasa Perangkat Lunak, Informatika, Bandung.

[6] Fathansyah, 2012, Basis Data., Informatika, Bandung 
[7] Hasugian, Humisar dan Ahmad Nur Shidiq, 2012, Rancang Bangun Sistem Informasi Industri Kreatif Bidang Penyewaan Sarana Olahraga, Seminar Nasional Teknologi Informasi \& Komunikasi Terapan 2012 (Semantik 2012), Semarang, 23 Juni 2012, 606-612.

[8] Shalahudin, M, Rosa, A.S, 2011, Java di Web. Informatika., Bandung

[9] Oktaviani, Anggi, 2016, E-Commerce Merchandise KPOP Pada Toko Haruna 88 Jakarta Menggunakan Unified Modeling Languange(UML), Vol.V No-1 Februari 2016, 12-19,Jurnal Sistem Informasi.

[10]Pranata Sentosa, Jony dan Nunung Hidayatun, 2016, Pendekatan Classic Life Cycle Dalam Perancangan Web E-Commerce Untuk Penjualan Pakaian Anime, Vol. V No.1 Februari 2016, 40-46, Jurnal Sistem Informasi.

[11]Wijaya, Tony dan Dony Pratama, 2014, Rancang Bangun Website E-Commerce Pada Barcelona Sport, Vol 4 No.1-2014, 74-84, Jurnal Ilmiah SISFOTENIKA. 